\title{
Is educational game effective in improving critical thinking skills?
}

\author{
Nur Fitriyadi *, Wuri Wuryandani \\ Universitas Negeri Yogyakarta. Jalan Colombo No. 1, Yogyakarta 55281, Indonesia \\ * Corresponding Author. Email: nurfitriyadi.2018@student.uny.ac.id
}

Received: 3 November 2020; Revised: 12 November 2020; Accepted: 2 December 2020

\begin{abstract}
This research is based on a needs analysis of interview result to the fifth grade elementary school teachers in Kalasan District, Sleman Regency, Yogyakarta Special Region who stated that educational game media was needed to enrich the variety of instructional media and improve students' critical thinking skills. The purpose of this research and development is to produce an appropriate and effective educational game. This product development relies on Borg \& Gall model which includes ten steps: information gathering, planning, initial product development, limited field trials, product revisions, expanded field trials, product revisions, operational field trials, final product revisions, and dissemination and implementation. Product trials were conducted at SD Negeri Sorogenen 2, SD Negeri Tamanan 1, and SD Negeri Tunjungsari 2 in Kalasan District, Sleman Regency, Yogyakarta Special Region. Practicality test was carried out by implementing questionnaires concerning teachers' and students' response after the learning process. Effectiveness test during the field trials was conducted using pretest-posttest questions. The results showed that the developed educational game was suitable for use according to media experts with a score of 85.71 or in 'Very Good' category and material experts with a score of 67.50 or in good category. Based on statistical tests, the educational game was proven to be effective in improving students' critical thinking skills during learning process.
\end{abstract}

Keywords: multimedia, educational games, critical thinking skills, elementary school

How to Cite: Fitriyadi, N., \& Wuryandani, W. (2021). Is educational game effective in improving critical thinking skills?. Jurnal Prima Edukasia, 9(1), 107-117. doi:https://doi.org/10.21831/jpe.v9i1.35475

\section{Introduction}

Critical thinking skills are an important ability for everyone to have. Without critical thinking, people are easily exploited politically and economically (Facione, 2013). Humans are demanded to be able to think at a critical level in order to compete in life (Yonanda, 2019). The ability to think critically is highly needed, thus it should be taught in schools (McPeck, 2017; Lastriningsih, 2017). This is because the ability to think critically has long-term benefits. These skills support students in managing their learning skills and encourage them to contribute creatively to the profession they will choose. In addition, students who possess critical thinking skills will be more skilled in composing questions or statements, checking the credibility of news sources, and making the best decisions (Sulistiani \& Masrukan, 2016).

The ability to think critically is a process that is carried out actively and skillfully in conceptualizing, applying, analyzing, synthesizing, and/or evaluating information collected from observations, experiences, reasoning, reflection, and communication results as a basis for acting and making decisions (Styron, 2014). Critical thinking becomes a provision for an individual's thinking process in making rational decisions based on what he/she believes (Ennis, 1993). Critical thinking skills have several indicators, including the ability to (1) formulate problems, (2) provide arguments, (3) formulate deduction and induction, (4) perform evaluation, and (5) decide and implement (Ennis, 1993).

The preliminary study to determine the level of critical thinking skills of the fifth grade students of the selecting elementary schools in Kalasan was conducted by interviewing homeroom teachers of the fifth graders on 18, 19, and 20 July 2019 . The subjects of the interview were the fifth grade teachers of SD Negeri Sorogenen 2, SD Negeri Tunjungsari 2, and two teachers of class VA and VB of SD Negeri Tamanan 1. The results of the interviews indicated that the students' critical thinking skills were 
Jurnal Prima Edukasia, 9 (1), 2021 - 108

Abdul Kadir, Kharis Sulaiman Hasri

still not as expected. Students often had difficulty in formulating problems and responding to complex problems at hand. Moreover, they always had difficulty in drawing conclusions without teacher's help.

The computer laboratory facilities provided by the three schools had not been used optimally as learning tools. Additionally, schools did not have sundry interactive multimedia yet. In fact, interesting and fun multimedia will trigger students' enjoyment in learning as well as keep them away from boredom. By employing multimedia, students will play as well as learn. The play-based learning approach is very suitable to be applied in elementary schools (Djatmika \& Kuswandi, 2017). Basically, elementary school students still love to play, therefore teachers should design their lessons which integrate learning material and game (Mardati \& Wangid, 2015).

Improving critical thinking skills should be conducted in the right way (Manek et al., 2019). In designing their learning, teachers cannot avoid the process of selecting appropriate learning media. Learning media is a tool which carries messages from learning sources to message recipients (Falahudin, 2014). Therefore, teachers need learning media as part of teaching aids (Astuti \& Mustadi, 2014). These media can be texts, images, audio, or animated videos which can attract students' attention. In a learning process, teachers need to use media in accordance with student characteristics. It will be better if the media are varied, selected alternatively to match the characteristic of learning material in order to avoid monotonous and boring learning process. In selecting the media, teachers should consider whether or not it is relevant, effective, efficient, interesting, and close to students' real life (Kusmayadi et al., 2017). The current learning process should be more focused on the use of technology and thinking skills development (Amrita \& Kuswanto, 2019).

One of the media that can be developed to achieve this goal is educational games. The educational games in question are games that can be played via a Personal Computer (PC) or laptop. (Smaldino et al., 2008) explain that educational games are instructional tools which support students in learning knowledge and skills and involve the use of problem solving strategies and techniques. Educational games are digital games designed for educational enrichment which support learning using multimedia technology (Shalahudin \& Rosa, 2011).

Considering the characteristics of fifth grade students of elementary school who still enjoy playing, educational games are good choice to be selected as learning media. Educational games have six main characteristics: fantasy, rules/objectives, sensory stimulation, challenge, mystery, and control(Garris et al., 2002). Wulandari, Susilo, \& Kuswandi (2016) explain the principles of educational games which include: (1) they must be educational, thus it can be the right media to help students achieve the expected competencies, (2) the creation technique should be appropriate and the material content should follow the curriculum rules, and (3) it is necessary to pay attention to the games' display which can attract students' attention.

Previously, there were some researchers conducted research and developments concerning educational game media. One of which was a plausible research and development carried out by Anditasari and Andajani (2018). The result of the analysis proved that content, language, presentation systematics, and appearance of their educational game were categorized as appropriate to be implemented in learning to write descriptive texts. Another research and development was conducted by Nasikhah (2016). Educational game media that had been developed meet the very feasible criteria as a learning medium with the evaluation result of its content, presentation of learning media, and language used were in very good criteria.

The lack of variation in school-owned multimedia which can be used by the fifth graders of elementary schools in Kalasan, Sleman, Yogyakarta Special Region has become the strong reason for developing educational games. Based on the needs analysis, teachers need educational games to enrich their choice of media to use in the learning process. The educational game of this study are packed with visuals effects, sound effects, and interesting animations as well as learning materials that are easy to understand. The learning materials chosen are theme 4 sub-themes 3 learning 5, of Bahasa Indonesian, natural science, and cultural art and crafts lessons.

\section{Method}

The method used for the basis of this educational game development is an adaptation of Borg \& Gall's model. This model is chosen because it has systematic steps which are easy to carry out. In addition, the developed product undergoes a set of revision stages to produce better product. Borg and 
Jurnal Prima Edukasia, 9 (1), 2021 - 109

Nur Fitriyadi, Wuri Wuryandani

Gall (1983) explain that development research in education includes ten steps. These steps are information gathering, planning, initial product development, limited field trials, product revisions, expanded field trials, product revisions, operational field trials, final product revisions, and dissemination and implementation.

This research and development was conducted from July 2019 to October 2020. The developed media were validated first by media experts and material experts. Validators provided input and suggestions related to the products. Furthermore, the products were revised and then tested on the user to obtain the attractiveness, practicality, and effectiveness data of the product. The user trial activity was conducted in three stages: (1) limited field trial, engaging a teacher and 3 fifth graders of SD Negeri Sorogenen 2, (2) expanded field trial, engaging two teachers and six fifth graders of SD Negeri Tamanan 1, and (3) operational field trial, engaging 29 fifth graders of SD Negeri Tunjungsari 2. During the field trials, the researchers conducted a critical thinking skills test in the form of pretest and posttest in order to find out the level of product effectiveness.

To collect the data, some instruments including interview guidelines, expert validation questionnaires, teacher and student response questionnaires, as well as pretest and posttest questions were applied. Interview guidelines were used for needs analysis. The material and media experts' validation sheet questionnaires were used to assess the validity of the media and as a medium to collect suggestions and input of improvement of the educational game. Teachers' and students' response questionnaires were employed to measure the attractiveness and effectiveness of the educational games. Meanwhile, the pretest and posttest questions were used to find out the effectiveness of educational games in improving students' critical thinking skills.

Data analysis techniques applied for this research and development included qualitative descriptive analysis and quantitative analysis. Qualitative data were obtained from the instruments of expert validations and user tests in the form of suggestions or input concerning the product. Qualitative descriptive analysis technique was used to analyze qualitative data in the form of input and suggestions from media expert and thematic material expert gathered through expert validation sheets as well as input and suggestions from the users. On the flip side, quantitative data analysis was employed to process the data obtained from the result of expert validity test as well as teachers' and students' responses questionnaire. Quantitative data analysis was also used to process data of field trial results in the form of students' pretest and posttest scores before and after using the media.

Assessment of the feasibility aspects of the material and media was conducted by converted the score obtained into percentage. The percentage obtained was then converted into qualitative data using a criteria formulated by Widoyoko (2015). The product would be certified as feasible if its percentage value was 61 or higher, and thus in good category. The assessment conversion using percentages was also used to determine the responses of teachers and students during limited field trials and expanded field trials.

Tabel 1. Criteria for Assessment Using Percentages Conversion

\begin{tabular}{cc}
\hline Percentage & Category \\
\hline $81,00-100 \%$ & Very Good \\
$61,00-80,00 \%$ & Good \\
$41,00-60,00 \%$ & Fair \\
$21,00-40,00 \%$ & Poor \\
$00,00-20,00 \%$ & Very Poor \\
\hline
\end{tabular}

The effectiveness of the product was analyzed after the pretest and posttest results during field trials were obtained. Pretest was applied to know the students' initial critical thinking skills, while posttest was used as the final evaluation given after they completed the learning process. Posttest was a medium to obtain an overview of students' critical thinking skills which had been achieved after they were treated using educational game media during the subject matter delivery. Data of the pretest and posttest results were then analyzed using paired sample $t$ test with the help of a computer program SPSS. Means difference test between pretest and posttest results was used to determine the research conclusions. This analysis aimed to determine the effect of educational game media on students' critical thinking skills. For this study, the product effectiveness test was conducted by comparing the means before and after the educational game media was used in learning. 
Jurnal Prima Edukasia, 9 (1), 2021 - 110

Abdul Kadir, Kharis Sulaiman Hasri

The hypothesis used in comparing the means before and after the application of educational game media was a two-tailed hypothesis: (1) $\mathrm{H} 0: \mu 1=\mu 2$ (there was no significant difference of critical thinking skills before and after); (2) $\mathrm{H1}: \mu 1 \neq \mu 2$ (there was a significant difference of critical thinking skills before and after). The critical point was alpha 0.05 and the critical area was degrees of freedom $(\mathrm{db})=\mathrm{n}-1=29-1=28$. If $\mid \mathrm{t}$ count $\mid>\mathrm{t}$ table it can be concluded that $\mathrm{H} 0$ is rejected and $\mathrm{H} 1$ is accepted.

\section{Results and Discussions}

Product of this research and development is a computer-based educational game media for fifth graders of elementary schools entitled " 5435 " which means grade 5 , theme 4 , sub-theme 3 , and learning 5 . The results of the educational game media development is elaborated as follows.

Needs analysis was carried out through a series of preliminary studies consisting of interviews with the fifth-grade teachers of SD Negeri Sorogenen 2, SD Negeri Tunjungsari 2, and SD Negeri Tamanan 1. The facilities in the three schools supported computer-based learning to be conducted. However, the facilities had not been used optimally. Computer laboratories were rarely used for learning. Therefore, educational game media were needed, not only because it was not available in the three schools yet, but also to enrich the variations of instructional media which can be used by teachers.

The product was developed using Articulate Storyline 3 software. In this multimedia there is an opening section and main menu containing core competence and basic competence indicators, learning materials, games, instructions, and developer profiles. Learning material for this educational game is fifth grade elementary school material, theme 4, sub-themes 3, learning 5, of Bahasa Indonesian, natural science, and cultural art and crafts lessons. The essence of this multimedia is a game which consists of three types of games, namely puzzle piece, remember pic, and mouse over. Educational game media navigation buttons are return to the main menu, continue, return, and exit from the media program. The media is stored in a flash drive in HTML5 format and can be run on a computer with a minimum processor specification Intel Pentium III $600 \mathrm{MHz}$ up to the latest. The minimum operating system that can be used to run this game is Windows XP.

This educational game development began with designing developmental plan in the form of (1) syllabus; (2) analysis of basic competency, indicators, and learning objectives; (3) lesson plan; and (4) pretest and posttest questions for field trials. This developmental plan was the basis for making flowcharts and storyboards. In the second stage, the researchers designed the flowcharts and storyboards by creating and installing media elements. This work was done by collecting materials in the form of images, audio, and texts, and then assembled them to create educational game media. The third stage comprised of loading the media into several flash drives. The final step was to validate the media prototypes by material expert and media expert.

Expert suggestions and comments served as references for product revisions. The revised product was then tried out to the users. The first step was limited field trial which engaged three fifth grade students of SD Negeri Sorogenen 2, comprised of high, medium, and low cognitive abilities students. The next stage was expanded field trial. This stage was carried out after the revision was done based on the result of limited field trial. The participants of expanded field trial was two teachers and six fifth grade students of SD Negeri Tamanan 1, comprised of students with high, medium, and low cognitive abilities, two students for each category. The last stage was operational field trial which was conducted to 29 fifth grade students of SD Negeri Tunjungsari 2.

The evaluation stage of this study which was the basis of the product revision, functioned as the determinant of product improvements and product feasibility. Evaluation was carried out by considering the validation of experts (media experts and material experts) and users (teachers and students). Product which had been validated by experts was then revised and tested to the users. The revision of each trial was needed for the next process so that the media development was in accordance with the expected objectives. Product that was tested by media experts and material experts was then validated using validation sheet questionnaires.

Aspects assessed by media experts included media content and objective, instructional quality, and media technical quality. The indicators of content and objective consisted of 7 statement items. Instructional quality indicators consisted of 4 statement items. Meanwhile, the technical quality indicators consisted of 3 statement items. Each indicator had a scale of 1-5. 
Jurnal Prima Edukasia, 9 (1), 2021 - 111

Nur Fitriyadi, Wuri Wuryandani

The percentage of the judgment results obtained from media experts is $85.71 \%$, therefore the final result of the product validity criteria is very good. Media expert claimed that all navigation buttons functioned properly. Some suggestions from media experts were about color and fonts selection. These suggestions were then used as revision guideline.

The product was also validated by material experts. Aspects that were assessed including accuracy, completeness, clarity, systematics, and material relevance. The accuracy indicator consisted of 8 statement items. The completeness indicator consisted of 2 statement items. The clarity indicator consisted of 2 statement items. Systematic indicators consisted of 2 statement items. Meanwhile, the material relevance indicator consisted of 2 statement items. Each indicator had a scale of 1-5.

The percentage of judgment results obtained from material experts is $67.50 \%$, thus the final result of the product validity criteria is good. According to the material expert, the material and games presented in the educational games needed to be made in such a way that it could encourage students more to think critically. Consequently, the material aspect was revised to produce educational game which was appropriate and effective for the limited field trial, expanded field trial, and operational field trial.

Limited field trial was conducted to three fifth grade students and their homeroom teacher at SD Negeri Sorogenen 2. The three students were selected under consideration that they were each had good, moderate, and less cognitive abilities according to the recommendation of the teacher. After taught using educational game media, each student filled out 17 statement items (yes/no) relating to the material, media, and usefulness. The results of the limited field trial data analysis are presented in Table 4.

Tabel 2. Data Analysis of Students' Response in Limited Field Trial

\begin{tabular}{cccc}
\hline Respondent & Obtained Score & Percentage & Category \\
\hline 1 & 15 & $88,24 \%$ & Very Good \\
2 & 17 & $100 \%$ & Very Good \\
3 & 16 & $94,11 \%$ & Very Good \\
Mean & 16 & $94,11 \%$ & Very Good \\
\hline
\end{tabular}

It is depicted in Table 4 that the average score percentage obtained is $94.11 \%$, therefore it is in very good criteria. Other than students, the teacher also filled out teacher response questionnaire regarding their assessment of the media. Aspects that were assessed included accuracy, completeness, clarity, systematics, material relevance, content and objectives, instructional quality, and technical quality. There were 27 statement items with a scale of 5 that the teacher must fill out after testing out the media. The results of teacher assessments can be seen in Table 5 .

Tabel 3. Data Analysis of Teacher Response in Limited Field Trial

\begin{tabular}{clccc}
\hline No. & \multicolumn{1}{c}{ Aspect } & Number of Question Items & Maximum Score & Obtained Score \\
\hline 1. & Accuracy & 5 & 25 & 24 \\
2. & Completeness & 2 & 10 & 9 \\
3. & Clarity & 2 & 10 & 10 \\
4. & Systematics & 2 & 10 & 10 \\
5. & Material relevance & 2 & 10 & 8 \\
6. & Content and objectives & 7 & 35 & 31 \\
7. & Instructional quality & 5 & 25 & 23 \\
8. & Technical quality & 2 & 10 & 8 \\
& Total & 27 & 135 & 123 \\
\hline
\end{tabular}

The percentage of teacher response scores concerning the limited field trial is $91,11 \%$ which is in the very good category. The result indicates that teacher's response of the educational game media during the limited field trial is very good. Some feedback obtained during the limited field trial were taken into consideration for the educational game improvement before expanded field trial was conducted. The suggestion in question was about the addition of game level.

After limited field trials and product revisions were conducted, expanded field trial was carried out. The expanded field trial involved 6 fifth grade students and 2 fifth grade teachers of SD Negeri Tamanan 1 . The six students were selected under consideration that they represented three cognitive ability groups (good, moderate, and less) according to the recommendation of the teacher. The data collection instrument for this trial was the same as the one used in the previous trial. The results of the students' response data analysis of the expanded field trial are showed in Table 6. 
Jurnal Prima Edukasia, 9 (1), 2021 - 112

Abdul Kadir, Kharis Sulaiman Hasri

Tabel 4. Data Analysis of Students' Response in Extended Field Trial

\begin{tabular}{cccc}
\hline Respondent & Obtained Score & Percentage & Category \\
\hline 1 & 17 & $100 \%$ & Very Good \\
2 & 16 & $94,11 \%$ & Very Good \\
3 & 12 & $70,59 \%$ & Good \\
4 & 16 & $94,11 \%$ & Very Good \\
5 & 16 & $94,11 \%$ & Very Good \\
6 & 17 & $100 \%$ & Very Good \\
Mean & 15,67 & $92,18 \%$ & Very Good \\
\hline
\end{tabular}

It can be seen in Table 4 that 5 students gave very good responses while one student provided good response. The average score of the all six students was 15.67. The percentage obtained is $91.11 \%$, thus it is in very good criteria. Therefore, it can be concluded that the students' response to the expanded field trial is very good. Two fifth grade teachers of SD Negeri Tamanan 1 who participated in the product trial provided media assessments through teacher response questionnaires. The results of teachers' response of the expanded field trial are elaborated in Table 7.

Tabel 5. Field Trial Data Analysis

\begin{tabular}{clcccc}
\hline \multirow{2}{*}{ No. Aspect } & \multicolumn{1}{c}{$\begin{array}{c}\text { Number of } \\
\text { Question Items }\end{array}$} & Maximum Score & Obtained Score & Obtained Score \\
\cline { 5 - 6 } & & 5 & 25 & Teacher 1 & Teacher 2 \\
\hline 1. & Accuracy & 2 & 10 & 6 & 19 \\
2. & Completeness & 2 & 10 & 8 & 6 \\
3. & Clarity & 2 & 10 & 8 & 8 \\
4. & Systematics & 2 & 10 & 7 & 7 \\
5. & Material relevance & 7 & 35 & 28 & 28 \\
6. & Content and objectives & 5 & 25 & 21 & 21 \\
7. & Instructional quality & 2 & 10 & 8 & 8 \\
8. & Technical quality & 27 & 135 & 104 & 105 \\
\hline
\end{tabular}

The results (in percentage) of teachers' response to the extended field trial is $77,41 \%$. The obtained percentage score of 77.41, based on the teachers' response to the expanded field trial meets good criteria. Therefore, it can be concluded that the teachers' response to the field trial is good.

After limited field trials, expanded field trials, and product revisions, operational field trials were conducted. The research subjects were 29 students of SD Negeri Tunjungsari 2 . The data obtained from this trial were pretest and posttest scores which were to measure students' critical thinking skills. For the pretest and posttest, the students were provided with 12 essay questions. The students would get 4 points for each correct answer. The comparison result of the mean scores before and after the application of educational games in learning can be seen in Table 8.

Tabel 6. Result of Mean Comparison Before and After Educational Games Application

\begin{tabular}{|c|c|c|c|c|c|}
\hline \multirow{3}{*}{$\overline{\text { Pair } 1}$} & & Mean & $\mathrm{N}$ & Std. Deviation & Std. Error Mean \\
\hline & Pretest & 29,38 & 29 & 5.790 & 1.075 \\
\hline & Posttest & 35,03 & 29 & 4.939 & 0.917 \\
\hline
\end{tabular}

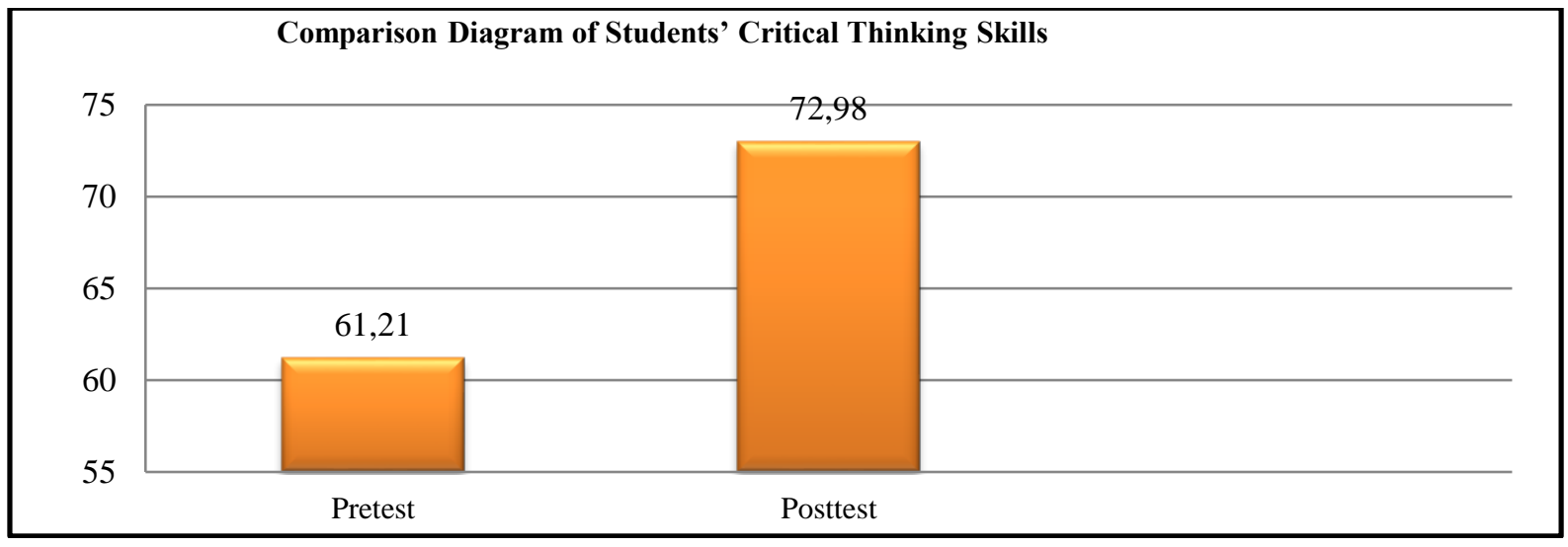

Figure 1. Comparison Diagram of Students' Critical Thinking Skills 
Jurnal Prima Edukasia, 9 (1), 2021 - 113

Nur Fitriyadi, Wuri Wuryandani

The obtained pretest mean score is 29.38 . If the score is converted into a percentage the result is $61,21 \%$. Meanwhile, the obtained posttest mean score is 35.03 . The conversion of the score into percentage is $72,98 \%$. The mean score of pretest < posttest, thus it can be said that there is critical thinking skills difference before and after learning with educational games. The following diagram pictures the comparison of the pretest and posttest scores.

The results of the correlation test between pretest and postest data show a correlation coefficient value of 0.237 with a significance value (sig) of 0.216 . Because the significance value is $0.216>0.05$, it can be said that there is a significant relation and influence between the application of educational games and students' critical thinking skills. To test this research and development hypothesis, paired sample test was conducted. The result can be seen in Table 10 .

Table 7. Paired Samples Test

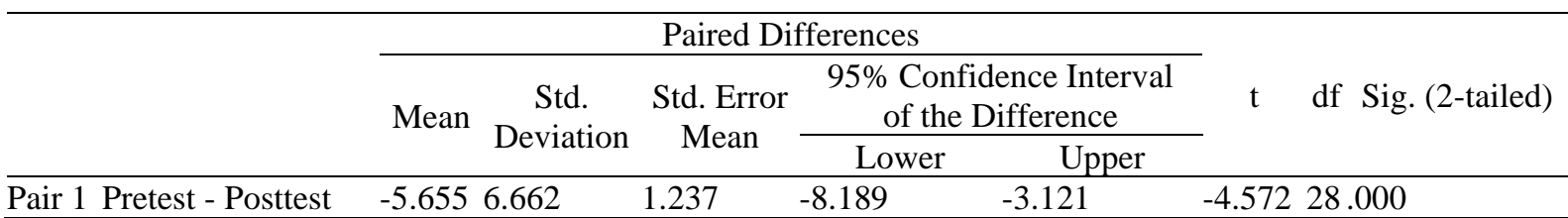

Based on the output of Paired Samples Test presented before, it is known that the $t$ count is negative, which is -4.572 because the pretest value is lower than the posttest. In this case, the value of $t$ count is positive, so that the value of $t$ is 4.572 . Furthermore, the $t$ table value is determined based on the degree of freedom (df) value and the significance value $(\mathrm{a} / 2)$. The df value is 28 and the value of $0.05 / 2$ is equal to 0.025 . This value is used as a reference in finding the $t$ table in the distribution of the $\mathrm{t}$-table statistical value. The result shows that the $\mathrm{t}$ table value is 2.04841 . Because $\mathrm{t}$ count $>\mathrm{t}$ table, it can be said that $\mathrm{H} 0$ is rejected while $\mathrm{H} 1$ is accepted. Thus, it can be concluded that there is a significant difference between students' critical thinking skills before and after the application of educational games in learning.

Students' critical thinking skills development after the application of educational game during the learning process is indeed according to the prediction. Game-based learning has received much attention from researchers and practitioners (Qian \& Clark, 2016). This is because digital game-based learning is a popular strategy to engage students by modifying learning process to more enjoyable (Carolyn Yang \& Chang, 2013).

Learning in the 21st century should be more technology-based (Kereluik et al., 2013). There are many technologies to be applied in learning. Today's technology, such as computers, can be used to hone students' critical thinking skills. Critical thinking skills are necessary to help individuals to be more adaptable, flexible, and better at handling rapidly developing information (Dwyer et al., 2014).

Strategies used to teach critical thinking skills include higher order questioning, cooperative learning, enrichment, modeling, real-life applications, and fostering affective domains (Lewis-Harris, 2010). Some of the components can be set in learning media in the form of educational games. This study implements higher order questioning manifested through problems questioning about critical thinking, active learning by encouraging students to actively conduct independent learning, and enrichment by exposing students to problem to solve through quizz and material, and understanding material through audiovisual learning.

The use of games in education is no longer a new thing (Çiftci, 2018). Digital games have been used as an effective tool to facilitate learning in various domains such as computer science, communication science, language learning, engineering, and health science (Barzilai \& Blau, 2014). In several previous studies, it is revealed that games are one of the learning media which can improve the quality of learning. Games are potential to improve the learning process in various ways (Torrente, 2010). Moreover, games are able to capture students' attention and keep students active during the learning process, which, in turn, can motivate them to learn. Thus, it is safe to say that game-based learning can stimulate a learning process which is able to increase student's learning motivation (Wang et al., 2011).

Educational games provide variation to the educational process (Giannakos, 2013). Educational games can be used as alternative learning media. By integrating educational games to the learning process, students will play and learn at the same time. The existence of educational games has a positive impact on the users' learning process (Noemí \& Máximo, 2014). In addition, activities which involve 
Jurnal Prima Edukasia, 9 (1), 2021 - 114

Abdul Kadir, Kharis Sulaiman Hasri

and motivate children, such as playing games, are ones that can be used to stimulate their knowledge and learning (Blades et al., 2013).

Educational games must be well designed to ensure student involvement as players (Kiili et al., 2012). Educational games also need to be designed to facilitate learning process by encouraging cognitive, behavioral, affective, and sociocultural involvement of students in the subject matter (Plass $\&$ Kaplan, 2016). Moreover, the game development should be based on an inquiry framework guidance, communication, mystery, decision making, challenge, and reward to be able to reach its goal which is to improve students' critical thinking skills (Hussein et al., 2019).

The selection of games as learning media is supported by previous researches. Cicchino (2015) applied game media to the learning process. The results confirmed that the use of games triggered a positive effect on students' learning outcomes. A similar study was conducted by Bakan (2018) and they concluded that educational games were effective in improving students' cognitive understanding and achievement.

The educational game developed here combines several elements including images, animation effects, sound effects, and videos into a game with several challenging levels to make it more interesting for students. The images contained in the game agree with theme 4 about health and folklore. Animation and sound effects are useful for attracting students' attention while videos are useful to help students understand the material more easily.

This educational game media is developed to assist teachers in improving students' critical thinking skills. The game media was assessed by material expert and media expert. The results of the assessments of the both experts indicate that this educational game media is apt to be used as a learning media. The material expert gave a score of 68 or categorized as "Good", while the score obtained from the media expert was 86 or in the "Very Good" category.

Teachers' and students' responses during the limited field trials and expanded field trials show that teachers and students were aided by the existence of educational game media used in the learning activities. In the limited field trial, the teacher and students scored 91 and 94 respectively which were in the "Very Good" category. Meanwhile in the expanded field trial, the teachers gave a score of 77 which was in the "Good" category and the students gave a score of 91 and was categorized as "Very Good". Based on operational field trials result, it could be seen that the developed educational game was effective in improving critical thinking skills. This was proved by the students' average pretest and posttest scores which increased from 61 to 73 . The educational game provides education that is relevant to the individual needs of students (Lee et al., 2016).

The improvement of students' critical thinking skills after the application of educational game is in line with the result of previous research conducted by Nafisa (2019) which showed that multimediaassisted discovery learning could improve students' critical thinking skills. It means that educational games as a type of multimedia can be used as effective learning media to improve critical thinking skills. Further, it also confirms the result of research conducted by Permatasari \& Setiawan (2020) caliming that educational games were effective for improving critical thinking skills of sixth grade elementary school students. As the conclusion, educational game media is indeed effective to improve students' critical thinking skills.

\section{Conclusions}

The developed educational game is suitable and effective to use in learning. This statement is supported by the result of media expert's judgment which is $85.71 \%$ and in 'Very Good' criteria, and material expert's validation which is $67.50 \%$, categorized as 'Good'. Limited field trial was conducted to three students and a class teacher of SD Negeri Sorogenen 2. The obtained score of students' response is $94.11 \%$ which is in 'Very Good' criteria. The score of teachers' response is $91.11 \%$ with 'Very Good' criteria. The expanded field trial was conducted to six students and two teachers of SD Negeri Tamanan 1. Students' response percentage is $92.18 \%$ with 'Very Good' criteria. The teachers' response percentage score is $77.41 \%$ with 'Good' criteria. The result of field trials show that the mean of pretest and posttest results increased from 61.21 to 72.98 . The $t$ test results confirm that the educational game is proved to be effective in improving students' critical thinking skills. 
Jurnal Prima Edukasia, 9 (1), 2021 - 115

Nur Fitriyadi, Wuri Wuryandani

\section{References}

Amrita, P. D., \& Kuswanto, H. (2019). Pengembangan mobile learning IPA (MLI) Sasirangan materi pencemaran lingkungan untuk peserta didik SMP. JTP - Jurnal Teknologi Pendidikan, 21(2), 151-164. https://doi.org/10.21009/jtp.v21i2.11446

Anditasari, R., \& Andajani, K. (2018). Pengembangan media berbasis permainan edukatif pada pembelajaran menulis teks deskripsi. Jurnal Pendidikan: Teori, Penelitian, Dan Pengembangan, 3(1), 107-114. https://doi.org/10.17977/jptpp.v3i1.10379

Astuti, Y. W., \& Mustadi, A. (2014). Pengaruh penggunaan media film animasi terhadap keterampilan menulis karangan narasi siswa kelas V SD. Jurnal Prima Edukasia, 2(2), 250. https://doi.org/10.21831/jpe.v2i2.2723

Bakan, U., \& Bakan, U. (2018). Game-based learning studies in education journals: A systematic review of recent trends. Actualidades Pedagógicas, 72, 119-145. https://doi.org/10.19052/ap.5245

Barzilai, S., \& Blau, I. (2014). Scaffolding game-based learning: Impact on learning achievements, perceived learning, and game experiences. Computers \& Education, 70, 65-79. https://doi.org/10.1016/j.compedu.2013.08.003

Blades, M., Blumberg, F. C., \& Oates, C. (2013). The importance of digital games for children and young people. Zeitschrift Für Psychologie, 221(2), 65-66. https://doi.org/10.1027/21512604/a000132

Borg, W. R., \& Gall, M. D. (1983). Educational research: An introduction. Longman.

Carolyn Yang, Y.-T., \& Chang, C. (2013). Empowering students through digital game authorship: Enhancing concentration, critical thinking, and academic achievement. Computers \& Education, 68, 334-344. https://doi.org/10.1016/j.compedu.2013.05.023

Cicchino, M. I. (2015). Using game-based learning to foster critical thinking in student discourse. Interdisciplinary Journal of Problem-Based Learning, 9(2). https://doi.org/10.7771/15415015.1481

Çiftci, S. (2018). The studies on educational digital games regarding children: A new word analysis approach. Turkish Online Journal of Educational Technology, 17(2), 158-168.

Djatmika, E. T., \& Kuswandi, D. (2017). Efektivitas pengembangan media permainan ular tangga sebagai sarana belajar tematik SD. Jurnal Pendidikan: Teori, Penelitian, Dan Pengembangan, 2(7), 910-918. https://doi.org/10.17977/jptpp.v2i7.9634

Dwyer, C. P., Hogan, M. J., \& Stewart, I. (2014). An integrated critical thinking framework for the 21st century. Thinking Skills and Creativity, 12, 43-52. https://doi.org/10.1016/j.tsc.2013.12.004

Ennis, R. H. (1993). Critical thinking assessment. Theory Into Practice, 32(3), 179-186. https://doi.org/10.1080/00405849309543594

Facione, P. A. (2013). Critical thinking: What it is and why it counts. In Insight Assesment. Measured Reasons and The California Academic Press. https://www.nyack.edu/files/CT_What_Why_2013.pdf

Falahudin, I. (2014). Pemanfaatan media dalam pembelajaran. Jurnal Lingkar Widyaiswara, 1(4), 104-117. https://juliwi.com/published/E0104/Paper0104_104-117.pdf

Garris, R., Ahlers, R., \& Driskell, J. E. (2002). Games, motivation, and learning: a research and practice model. Simulation \& Gaming, 33(4), 441-467. https://doi.org/10.1177/1046878102238607

Giannakos, M. N. (2013). Enjoy and learn with educational games: Examining factors affecting learning performance. Computers \& Education, 68, 429-439. https://doi.org/10.1016/j.compedu.2013.06.005

Hussein, M. H., Ow, S. H., Cheong, L. S., \& Thong, M.-K. (2019). A digital game-based learning method to improve students' critical thinking skills in elementary science. IEEE Access, 7 , 96309-96318. https://doi.org/10.1109/ACCESS.2019.2929089 
Jurnal Prima Edukasia, 9 (1), 2021 - 116

Abdul Kadir, Kharis Sulaiman Hasri

Kereluik, K., Mishra, P., Fahnoe, C., \& Terry, L. (2013). What knowledge is of most worth. Journal of Digital Learning in Teacher Education, 29(4), 127-140.

https://doi.org/10.1080/21532974.2013.10784716

Kiili, K., de Freitas, S., Arnab, S., \& Lainema, T. (2012). The design principles for flow experience in educational games. Procedia Computer Science, 15, 78-91. https://doi.org/10.1016/j.procs.2012.10.060

Kusmayadi, K., Suyitno, I., \& Maryaeni, M. (2017). Pengembangan multimedia cerita rakyat sebagai penumbuh karakter siswa. Jurnal Pendidikan: Teori, Penelitian, Dan Pengembangan, 2(7), 902-909. https://doi.org/10.17977/jptpp.v2i7.9630

Lastriningsih, L. (2017). Peningkatan berpikir kritis dan prestasi belajar melalui metode inquiry pada siswa kelas IV SD. Jurnal Prima Edukasia, 5(1), 68-78. https://doi.org/10.21831/jpe.v5i1.7714

Lee, H., Parsons, D., Kwon, G., Kim, J., Petrova, K., Jeong, E., \& Ryu, H. (2016). Computers \& Education Cooperation begins : Encouraging critical thinking skills through cooperative reciprocity using a mobile learning game. Computers \& Education, 97, 97-115. https://doi.org/10.1016/j.compedu.2016.03.006

Lewis-Harris, J. (2010). Personal reflection: A reflection on encouraging critical thinking and empathy: Using so-TL to examine teaching effectiveness in a social justice in graduate education class. International Journal for the Scholarship of Teaching and Learning, 4(1), n1.

Manek, A. H., Utomo, D. H., \& Handoyo, B. (2019). Pengaruh model spasial based learning terhadap kemampuan berpikir kritis siswa. Jurnal Pendidikan: Teori, Penelitian, Dan Pengembangan, 4(4), 440-446. https://doi.org/10.17977/jptpp.v4i4.12245

Mardati, A., \& Wangid, M. N. (2015). Pengembangan media permainan kartu gambar dengan teknik make a match untuk kelas I SD. Jurnal Prima Edukasia, 3(2), 120-132. https://doi.org/10.21831/jpe.v3i2.6532

McPeck, J. E. (2017). Critical thinking and educational (12th ed.). Routledge.

Nafisa, D. (2019). Model pembelajaran discovery learning berbantuan multimedia untuk meningkatkan kemampuan berpikir kritis siswa. PRISMA, Prosiding Seminar Nasional Matematika, 2, 854-861. https://journal.unnes.ac.id/sju/index.php/prisma/article/view/29280

Nasikhah, A. N., Widihastrini, F., \& Widodo, S. T. (2016). Pengembangan game education pembelajaran PKN materi menghargai keputusan bersama kelas V SD. Jurnal Kreatif: Jurnal Kependidikan Dasar, 7(1), 81-91. https://doi.org/10.15294/kreatif.v7i1.9370

Noemí, P., \& Máximo, S. H. (2014). Educational games for learning. Universal Journal of Educational Research, 2(3), 230-238. https://doi.org/10.13189/ujer.2014.020305

Permatasari, K., \& Setiawan, Y. (2020). Meningkatkan minat dan berpikir kritis siswa kelas 6 SD melalui pengembangan game the rotation. Jurnal Pendidikan Tambusai, 4(2015), 1408-1418. https://doi.org/10.31004/jptam.v4i2.606

Plass, J. L., \& Kaplan, U. (2016). Emotional design in digital media for learning. In Emotions, Technology, Design, and Learning (pp. 131-161). Elsevier. https://doi.org/10.1016/B978-0-12801856-9.00007-4

Qian, M., \& Clark, K. R. (2016). Game-based Learning and 21st century skills: A review of recent research. Computers in Human Behavior, 63, 50-58. https://doi.org/10.1016/j.chb.2016.05.023

Smaldino, S. E., Lowther, D. L., Russell, J. D., \& Mims, C. (2008). Instructional technology and media for learning. Pearson Merrill Prentice Hall.

Styron, R. A. (2014). Critical thinking and collaboration: A strategy to enhance student learning. Journal of Systemics, Cybernetics and Informatics, 12(7), 25-30. http://www.iiisci.org/journal/CV\$/sci/pdfs/EI597JP12.pdf

Sukamto, R. A., \& Shalahuddin, M. (2013). Rekayasa perangkat lunak (terstruktur dan berorientasi objek). Informatika.

Sulistiani, E., \& Masrukan, M. (2016). Pentingnya berpikir kritis dalam pembelajaran matematika untuk menghadapi tantangan MEA. Prosiding Seminar Nasional Matematika X Universitas Negeri Semarang 2016, 605-612. 
Jurnal Prima Edukasia, 9 (1), 2021 - 117

Nur Fitriyadi, Wuri Wuryandani

https://journal.unnes.ac.id/sju/index.php/prisma/article/view/21554

Torrente, J. (2010). Introducing educational games in the learning process. IEEE Educon Education Engineering, 1121-1126. https://doi.org/https://ieeexplore.ieee.org/abstract/document/5493056/

Wang, C.-S., Liu, C.-C., \& Li, Y.-C. (2011). A game-based learning content design framework for the elementary school children education. The 16th North-East Asia Symposium on Nano, Information Technology and Reliability, 53-57. https://doi.org/10.1109/NASNIT.2011.6111121

Widoyoko, S. E. P. (2015). Evaluasi program pembelajaran: panduan praktis bagi pendidik dan calon pendidik (Cet. ke-3). Pustaka Pelajar. https://doi.org/2013

Wulandari, R., Susilo, H., \& Kuswandi, D. (2016). Multimedia Interaktif Bermuatan Game Edukasi sebagai Salah Satu Alternatif Pembelajaran IPA di Sekolah Dasar. Seminar Nasional Pengembangan Profesionalisme Pendidik Untuk Membangun Karakter Anak Bangsa, 1-8.

Yonanda, D. A. (2019). Pengembangan model pembelajaran inquiry berbasis saintifik terhadap kemampuan berpikir kritis siswa. JTP - Jurnal Teknologi Pendidikan, 21(1), 12-23. https://doi.org/10.21009/jtp.v21i1.8674 